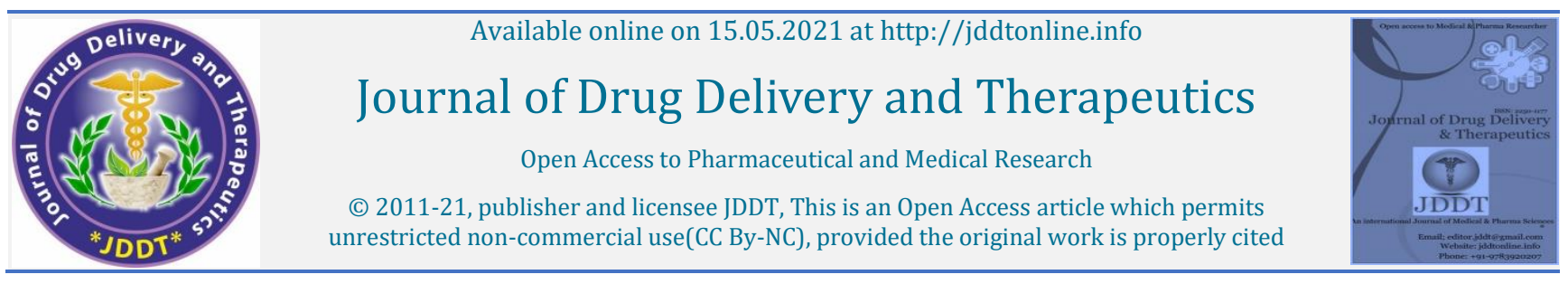

Open Access Full Text Article

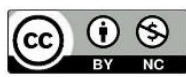

Research Article

\title{
Formulation and preclinical evaluation of Anti-inflammatory activity of Triticum aestivum
}

\author{
Sai Krishna Priya Dasari*, Pallavi Vadlamudi, Rama Rao Nadendla \\ Department of Pharmaceutics, Chalapathi Institute of Pharmaceutical Sciences, Chalapathi Nagar, Lam, Andhra Pradesh, Guntur-522034, India
}

\section{Article Info}

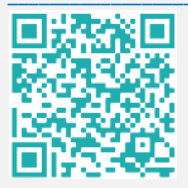

\section{Article History:}

Received 19 March 2021 Reviewed 26 April 2021

Accepted 03 May 2021 Published 15 May 2021

Cite this article as:

Dasari SKP, Vadlamudi P, Nadendla RR, Formulation and preclinical evaluation of Anti-inflammatory activity of Triticum aestivum, Journal of Drug Delivery and Therapeutics. 2021; 11(3):65-69

DOI: http://dx.doi.org/10.22270/jddt.v11i3.4781

\section{Abstract}

A wide scope of medical advantages has been credited to wheatgrass, the young grass of the wheat plant Tritium aestivum. Wheat grass is a decent wellspring of mineral supplements. It contains critical measures of iron, phosphorous, magnesium, manganese, copper and zinc. Wheatgrass is a rich supplement of tocopherols with high vitamin $\mathrm{E}$ content. Wheatgrass is beneficial in restoring more infections due to its significant function that, it can arrest the development of antagonistic microbes which are responsible for spreading certain diseases. constituents of wheatgrass may be obtained from fresh juice, frozen juice, powder, tablets with compositions differing as per their production methods which otherwise depends on growing conditions of wheatgrass. Anti-inflammatory activity of wheatgrass tablets was assessed by using formalin induced rat paw edema model. The results obtained were compared with aceclofenac, standard drug.

Keywords: Triticum aestivum, Flaxseed gel, Anti-inflammatory, Aceclofenac, Formalin.

*Address for Correspondence:

Sai Krishna Priya Dasari, Department of Pharmaceutics, Chalapathi Institute of Pharmaceutical Sciences, Chalapathi Nagar, Lam, Andhra Pradesh, Guntur-522034 India

\section{INTRODUCTION:}

The wheatgrass juice (WGJ) contains a high concentration of vitamin C. WGJ contains a lot of highly functional nutritive ingredients potent to unify the liver with the kidneys for detoxification of the organs and filtration of the blood to build a strong immune system. Wheatgrass extract has antimicrobial activities ${ }^{\mathbf{1}}$. Wheatgrass is known to help wellbeing and insistence both in humans and animals. Triticum aestivum has been utilized as natural medication in present and past and is highly esteemed for its therapeutic and nutritional properties ${ }^{2}$. Wheatgrass is a food that is prepared from cotyledons of Triticum aestivum. It contains amino acids, chlorophyll, vitamins, minerals and enzymes. It is gluten free. Wheatgrass is a good source of potassium, likewise a generally excellent source of dietary fiber, vit A, vit $\mathrm{E}$ (alpha tocopherol), vit $\mathrm{K}$ etc. Wheatgrass is likewise very nutritious. Wheatgrass juice supports weight reduction since it is rich in fiber content. Leaves of wheatgrass rises the activities of liver elements, as well as lipid peroxidation ${ }^{3}$.Wheatgrass is effective in serious cases of stomach ache, gas, paralysis, contamination of stomach, heart attack, diabetes, asthma, constipation, leukemia and other malignancy ${ }^{4}$. Wheatgrass extract is also utilized as effective haemostatic agent, anti-inflammatory agent, stimulant of fibroblasts, with a wide scope of healing properties. Its significant levels of proteins and amino acids work like natural cleanser to detoxify the liver, eliminate poisonous heavy metals from the circulatory system, free the group of squander matter, and hinder the pre maturing cycle5. The anti inflammatory properties of wheatgrass applies a constructive effect on diminishing pain and swelling6. The fermented wheatgrass extract improves high threat of survival of skin melanoma patients ${ }^{7}$.

\section{MATERIALS AND METHODS}

\section{Extraction of wheatgrass powder}

For extraction of wheatgrass powder for manufacturing of wheatgrass tablets, wheat grains should be washed thoroughly and then soaked in water for 6 hrs or over night. Later the water must be removed from grains and it should be kept in cotton cloth for $12 \mathrm{hrs}$ until it gives sprouts, these sprouts should be spread in the tray containing soil. Use the spray bottle filled with water to lightly sprinkle on the soil before going to bed, so the seedlings will be moist over night. Grass is usually ready to harvest after 9 to 10 days of growth. It must be cut at the edges so that it can give the second crop. Rinse the grass lightly as it doesn't need heavy washing as it is grown from organic seeds from organic soil or compost. Juice it in a blender and strain it to remove the solids. This juice is filtered in a vacuum filtration to remove the particles. The wheat grass juice thus obtained is transferred to a spray drier to get powdered wheat grass.

\section{Preparation of wheatgrass tablets}

Flaxseed gel is added to the spray dried powder which acts as a binder in the preparation of tablets by wet granulation method. The tablets were compressed after addition of other excipients. 
Table 1: Formulation table

\begin{tabular}{|c|c|c|c|c|c|c|}
\hline Ingredients & F1 & F2 & F3 & F4 & F5 & F6 \\
\hline Spray dried wheat grass powder(mg) & 100 & 200 & 250 & 300 & 400 & 500 \\
\hline Flaxseed gel & q.s & q.s & q.s & q.s & q.s & q.s \\
\hline Starch(gm) & 0.025 & 0.025 & 0.025 & 0.025 & 0.025 & 0.025 \\
\hline Magnesium stearate (gm) & 0.01 & 0.01 & 0.01 & 0.01 & 0.01 & 0.01 \\
\hline Talc(gm) & 0.0075 & 0.0075 & 0.0075 & 0.0075 & 0.0075 & 0.0075 \\
\hline
\end{tabular}

\section{Evaluation of prepared formulations:}

\section{Hardness}

The hardness of a tablet was tested using Pfizer hardness tester ${ }^{8}$.

\section{Friability}

The friability of the tablets was calculated by using a Lab India tablet friability tester. Tablets were taken, weighed and initial weight was noted $\left(\mathrm{W}_{0}\right)$. The tablets were allowed to rotate in the drum at $25 \mathrm{rpm}$ for 4 minutes and weighed (W) again. Percentage friability was calculated 9 .

\section{Content uniformity}

20 tablets were crushed in mortar and pestle, and weighed powder equivalent to $10 \mathrm{mg}$ of drug was taken and dissolved in $10 \mathrm{ml}$ of $0.1 \mathrm{~N} \mathrm{HCL}$ and the solution was then filtered through membrane filters of $0.45 \mu \mathrm{m}$, after suitable dilution with $0.1 \mathrm{~N} \mathrm{HCL}$, the drug content was spectrophotometrically analyzed at $\lambda \max 249 \mathrm{~nm}$.

\section{Invitro disintegration}

The invitro disintegration was as carried out using a Lab India tablet disintegrating tester (Model No. 251 DT1000). Six tablets are placed in each tube of disintegrating test apparatus and the time for disintegration was noted at $37 \pm$ $0.5^{\circ} \mathrm{C}$ using $900 \mathrm{ml}$ of $0.1 \mathrm{~N} \mathrm{HCL}$.

\section{Invitro drug release profile}

The in-vitro dissolution was carried out using paddle apparatus, the dissolution medium was 0.1N HCL, the temperature was maintained at $37 \pm 0.5^{\circ} \mathrm{c}$, and $50 \mathrm{rpm}$. Aliquots of $5 \mathrm{ml}$ samples were withdrawn at predetermined time intervals of 5, 10, 15, 20,25, 30 minutes and maintained sink condition with the same dissolution medium. The withdrawn samples were filtered through a membrane filter of $0.45 \mu \mathrm{m}$ and analyzed by using a UV- spectrophotometer at $249 \mathrm{~nm}^{\mathbf{1 0}}$.

\section{RESULTS AND DISCUSSION}

Table 2: Pre compression parameters for the formulation of F1 to F6

\begin{tabular}{|l|l|l|l|l|l|}
\hline Formulation code & Angle of repose & Bulk density & $\begin{array}{l}\text { Tapped } \\
\text { density }\end{array}$ & $\begin{array}{l}\text { Carr's } \\
\text { compressibility }\end{array}$ & Hausner's ratio \\
\hline F1 & $23.41 \pm 0.97$ & $0.24 \pm 0.03$ & $0.28 \pm 0.04$ & $8.82 \pm 0.09$ & $1.05 \pm 0.01$ \\
\hline F2 & $24.58 \pm 1.22$ & $0.27 \pm 0.03$ & $0.27 \pm 0.04$ & $6.01 \pm 1.26$ & $1.09 \pm 0.01$ \\
\hline F3 & $22.98 \pm 0.71$ & $0.27 \pm 0.04$ & $0.31 \pm 0.05$ & $10.75 \pm 1.12$ & $1.12 \pm 0.01$ \\
\hline F4 & $23.81 \pm 1.89$ & $0.27 \pm 0.03$ & $0.29 \pm 0.05$ & $11.40 \pm 2.32$ & $1.12 \pm 0.02$ \\
\hline F5 & $24.56 \pm 1.08$ & $0.26 \pm 0.04$ & $0.31 \pm 0.04$ & $9.67 \pm 3.33$ & $1.10 \pm 0.04$ \\
\hline F6 & $24.24 \pm 0.87$ & $0.25 \pm 0.03$ & $0.30 \pm 0.04$ & $11.71 \pm 0.16$ & $1.13 \pm 0.02$ \\
\hline
\end{tabular}

Table 3: Post compression parameters for the formulation of F1 to F6

\begin{tabular}{|c|c|c|c|c|c|}
\hline $\begin{array}{l}\text { Formulation } \\
\text { code }\end{array}$ & $\begin{array}{l}\text { Hardness } \\
\left(\mathrm{kg} / \mathrm{cm}^{2}\right)\end{array}$ & Friability (\%) & $\begin{array}{l}\text { Content } \\
\text { uniformity }\end{array}$ & $\begin{array}{l}\text { Disintegration } \\
\text { time (sec) }\end{array}$ & $\begin{array}{l}\text { Percent drug } \\
\text { release }\end{array}$ \\
\hline F1 & $4.3 \pm 0.11$ & $0.71 \pm 0.04$ & $98.1 \pm 1.14$ & $7 \mathrm{~min} 50 \mathrm{sec}$ & $96.62 \pm 0.75$ \\
\hline F2 & $4.1 \pm 0.25$ & $0.74 \pm 0.09$ & $98.9 \pm 0.78$ & $7 \mathrm{~min} 10 \mathrm{sec}$ & $93.5 \pm 0.83$ \\
\hline F3 & $4.6 \pm 0.54$ & $0.72 \pm 0.02$ & $98.6 \pm 0.58$ & $6 \min 8 \mathrm{sec}$ & $97.6 \pm 0.51$ \\
\hline F4 & $4.4 \pm 0.54$ & $0.78 \pm 0.01$ & $97.1 \pm 1.54$ & $7 \min 6 \mathrm{sec}$ & $98.7 \pm 0.41$ \\
\hline F5 & $4.3 \pm 0.51$ & $0.75 \pm 0.01$ & $98.2 \pm 1.15$ & $8 \mathrm{~min} 10 \mathrm{sec}$ & $97.6 \pm 0.42$ \\
\hline F6 & $4.5 \pm 0.23$ & $0.69 \pm 0.04$ & $99.2 \pm 1.24$ & $6 \min 4 \mathrm{sec}$ & $98.9 \pm 0.51$ \\
\hline
\end{tabular}

Fourier transform infrared (FT-IR) studies 
The FTIR spectrum of pure wheatgrass exhibited characteristic signals at $3282.98 \mathrm{~cm}^{-1}(\mathrm{O}-\mathrm{H}$ stretching vibrations),2917.68 cm${ }^{1}$ (N-H stretching vibration), $1637.27 \mathrm{~cm}^{-1}$ (C=C stretching vibration), $1052.48 \mathrm{~cm}^{-1}(\mathrm{C}-0$ stretching vibration).

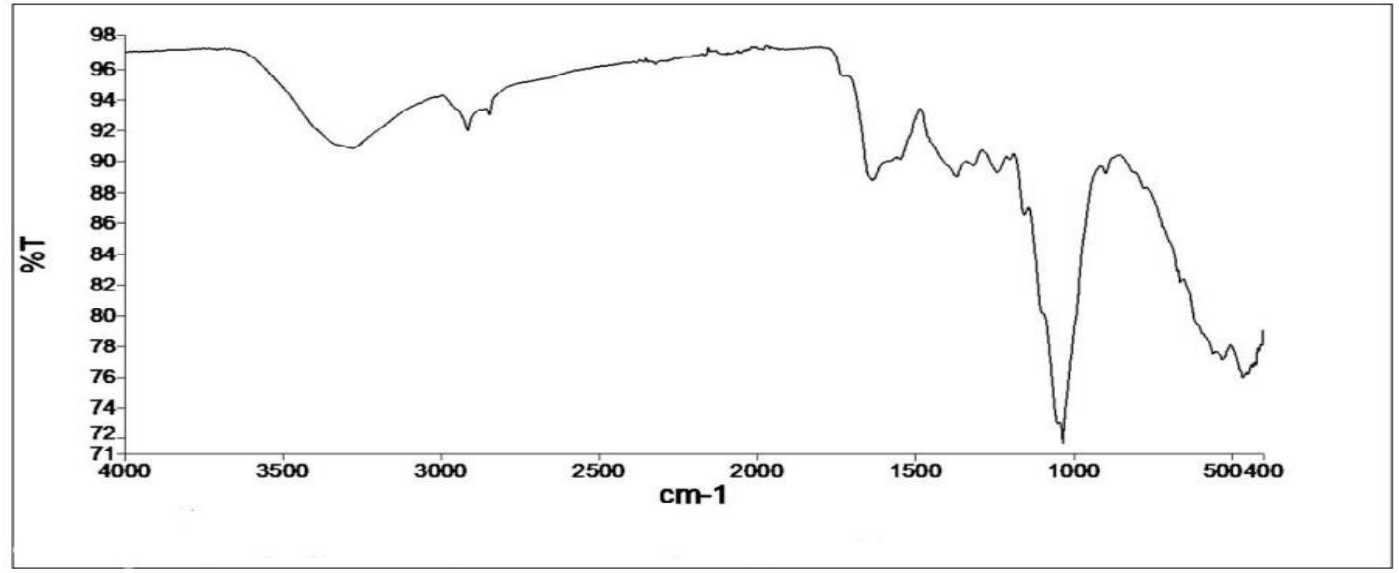

The FTIR spectrum of flaxseed gel exhibited characteristic signals at $3384.28 \mathrm{~cm}^{-1}\left(\mathrm{~N}-\mathrm{H}\right.$ stretching vibration), $1636.34 \mathrm{~cm}^{-1}(\mathrm{C}=\mathrm{C}$ stretching vibration).

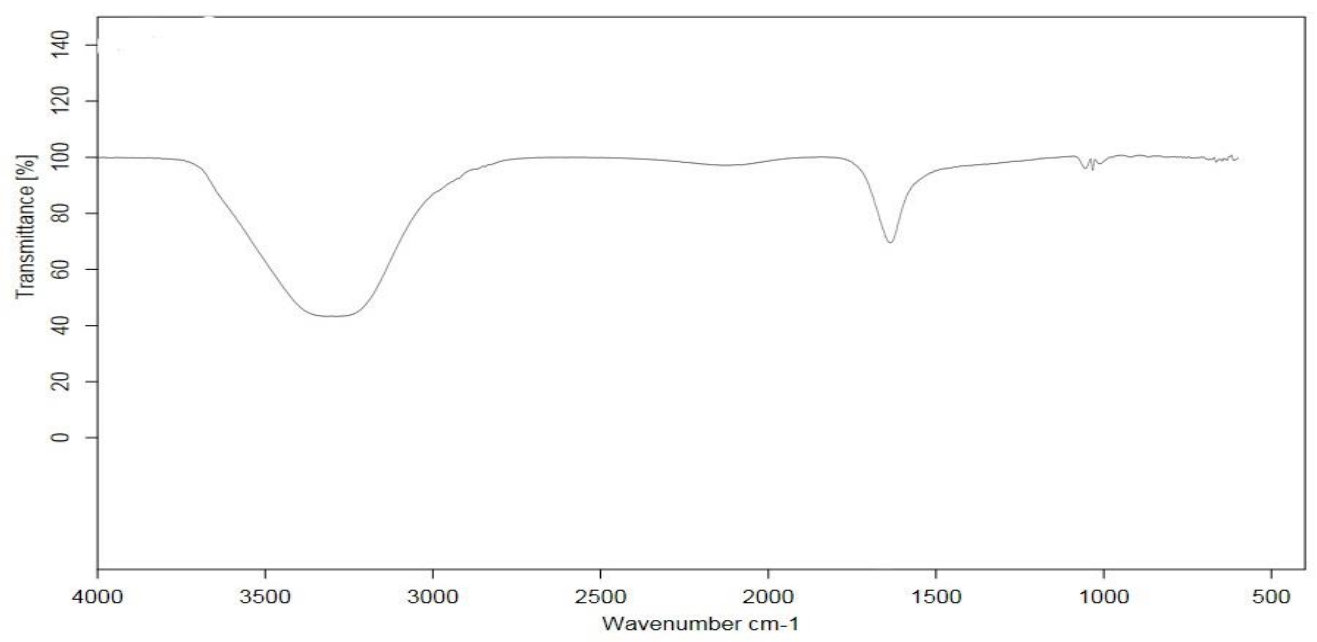

The FTIR spectrum of wheatgrass and flaxseed granules exhibited characteristic vibrations at $3356.04 \mathrm{~cm}^{-1}(\mathrm{~N}-\mathrm{H}$ stretching vibration), $1408.16 \mathrm{~cm}^{-1}$ (O-H bending vibration), $1065.27 \mathrm{~cm}^{-1}$ (C-O stretching vibration).

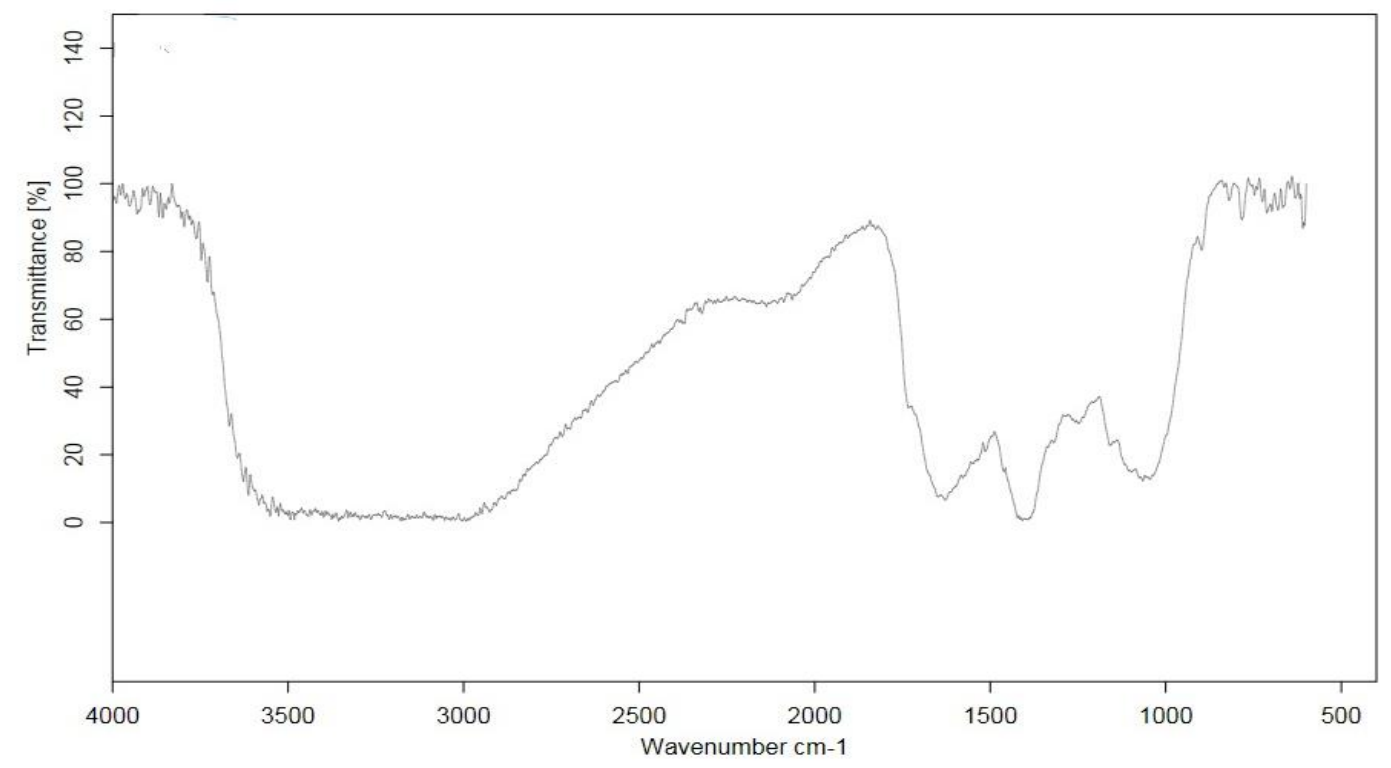




\section{Preclinical evaluation}

Albino wistar rats weighing between 150-200 g kept under standard condition in the animal house of the college were utilized for the investigation. Every animal was fasted with water over night. Edema was induced using formalin. Formulation F6 with high drug content was selected as the optimized formulation and was taken for preclinical study.

Table 4: Effect of vehicle on formalin induced paw edema in rats

\begin{tabular}{|l|l|l|l|}
\hline Animal no. & Initial paw volume (ml) & $\begin{array}{l}\text { Paw volume after 5 hours } \\
\text { (ml) }\end{array}$ & $\begin{array}{l}\text { Difference in paw volume } \\
\text { (edema) }\end{array}$ \\
\hline 1 & 69 & 133 & 64 \\
\hline 2 & 73 & 142 & 70 \\
\hline 3 & 72 & 124 & 51 \\
\hline 4 & 74 & 144 & 69 \\
\hline 5 & 75 & 135 & 61 \\
\hline 6 & 71 & 143 & 72 \\
\hline Mean \pm SEM & $72.33 \pm 0.8819$ & $136.83 \pm 3.156$ & $64.5 \pm 3.17$ \\
\hline
\end{tabular}

Number of animals used are 6 in each group

Table 5: Effect of dispersed wheat grass tablet on formalin induced paw edema in rats

\begin{tabular}{|l|l|l|l|}
\hline Animal no. & Initial paw volume (m) & $\begin{array}{l}\text { Paw volume after 5 hours } \\
(\mathbf{m l})\end{array}$ & $\begin{array}{l}\text { Difference in paw volume } \\
\text { (edema) }\end{array}$ \\
\hline 1 & 68 & 81 & 13 \\
\hline 2 & 74 & 95 & 21 \\
\hline 3 & 65 & 86 & 21 \\
\hline 4 & 55 & 74 & 19 \\
\hline 5 & 69 & 84 & 15 \\
\hline 6 & 64 & 78 & 14 \\
\hline Mean \pm SEM & $65.83 \pm 2.60$ & $83 \pm 2.996$ & $17.166 \pm 1.47$ \\
\hline
\end{tabular}

Number of animals used are 6 in each group

Table 6: Effect of aceclofenac tablet on formalin induced paw edema in rats

\begin{tabular}{|l|l|l|l|}
\hline Animal no. & Initial paw volume (m) & $\begin{array}{l}\text { Paw volume after 5 hours } \\
\text { (ml) }\end{array}$ & $\begin{array}{l}\text { Difference in paw volume } \\
\text { (edema) }\end{array}$ \\
\hline 1 & 73 & 90 & 17 \\
\hline 2 & 75 & 86 & 11 \\
\hline 3 & 76 & 90 & 14 \\
\hline 4 & 80 & 96 & 16 \\
\hline 5 & 79 & 85 & 6 \\
\hline 6 & 71 & 81 & 10 \\
\hline Mean \pm SEM & $75.67 \pm 1.406$ & $88 \pm 2.113$ & $12.34 \pm 1.687$ \\
\hline
\end{tabular}

Number of animals used are 6 in each group

Table 7: Effect of various treatments on formalin induced paw edema in rats

\begin{tabular}{|l|l|l|l|l|}
\hline Treatments & $\begin{array}{l}\text { Initial paw volume } \\
(\mathbf{m l})\end{array}$ & $\begin{array}{l}\text { Paw volume after 5 } \\
\text { hrs (ml) }\end{array}$ & $\begin{array}{l}\text { Increase in paw } \\
\text { volume (ml) }\end{array}$ & \% Inhibition \\
\hline Control & $72.33 \pm 0.8819$ & $136.863 \pm 3.156$ & $64.5 \pm 3.17$ & - \\
\hline Aceclofenac & $75.67 \pm 1.406$ & $88 \pm 2.113$ & $12.34 \pm 1.687$ & 80.87 \\
\hline Wheatgrass tablet & $65.83 \pm 2.60$ & $83 \pm 2.996$ & $17.166 \pm 1.47$ & 73.379 \\
\hline
\end{tabular}




\section{DISCUSSION}

The beneficial effect of wheatgrass in skin diseases and anti inflammatory activity was studied using formalin-induced rat paw edema as the experimental model in the present project. Results of the study have shown that the dispersed tablet of wheatgrass possess a significant anti-inflammatory activity against chronic paw edema induced by formalin. Maximum anti-inflammatory activity was observed after 5 hours of administration of the wheatgrass formulation.

\section{ACKNOWLEDGEMENT}

The authors are grateful to the management and principal of Chalapathi Institute of Pharmaceutical Sciences for providing the necessary resources for the successful completion of the research work.

\section{REFERENCES:}

1. Sundaresan A, Selvi A, Manonmani HK. The Anti-Microbial Properties of Triticum aestivum ( Wheat Grass ) Extract. Int J Biotechnol Wellness Ind. 2015; 2015(4):84-91.

2. Rana S, Kamboj JK, Gandhi V. Living life the natural way Wheatgrass and health. Funct Foods Heal Dis. 2011; 1(11):44456.

3. Arya P, Kumar M. Chemoprevention by Triticum aestivum of mouse skin carcinogenesis induced by DMBA and croton oil -
Association with oxidative status. Asian Pacific J Cancer Prev [Internet]. 2011 [cited 2021 Apr 30]; 12(1):143-8. Available from: https://pubmed.ncbi.nlm.nih.gov/21517247/

4. Fahey JW, Stephenson KK, Dinkova-Kostova AT, Egner PA Kensler TW, Talalay P. Chlorophyll, chlorophyllin and related tetrapyrroles are significant inducers of mammalian phase 2 cytoprotective genes. Carcinogenesis. 2005; 26(7):1247-55.

5. Wheat J, Currie G. Herbal medicine for cancer patients: An evidence based review. Internet J Altern Med. 2012; 5(2):1-11.

6. Nenonen MT, Helve TA, Rauma A-L, Hänninen OO, Hänninen H. UNCOOKED, LACTOBACILLI-RICH, VEGAN FOOD AND RHEUMATOID ARTHRITIS. Vol. 37, British Journal of Rheumatology. 1998.

7. Demidov L V., Manziuk L V., Kharkevitch GY, Pirogova NA, Artamonova E V. Adjuvant fermented wheat germ extract (AvemarTM) nutraceutical improves survival of high-risk skin melanoma patients: A randomized, pilot, phase II clinical study with a 7-year follow-up. Cancer Biother Radiopharm. 2008; 23(4):477-82.

8. Patel D, Patel U, Shukla M, Bhimani B, Patel G. Formulation and Evaluation of Immediate Release Tablet of Simvastatin. Res J Pharm Technol. 2020; 13(1):421.

9. Kulkarni RS, Behera AL. Formulation and Evaluation of Immediate Release Tablet of Valsartan. Int J Pharm Sci Res [Internet]. 2015; 6(2):808. Available from: http://dx.doi.org/10.13040/IJPSR.0975-8232.6

10. Nyol S, Gupta MM. Immediate Drug Release Dosage Form: a Review. J Drug Deliv Ther. 2013; 3(2):155-61. 